\title{
COMMANDING AND DEFINING. ON EUGENIO BULYGIN'S THEORY OF LEGAL POWER-CONFERRING RULES
}

\author{
GonZalo Villa Rosas \\ Rechtswissenschaftliche Fakultät \\ Christian-Albrechts Universität zu Kiel \\ villarosasgonzalo@gmail.com
}

SUMMARY: This paper aims to explore two objections raised against Bulygin's second approach to the definition of the nature of legal power-conferring rules. According to the first objection, such an account is vague about what is defined by legal powerconferring rules qua constitutive rules. I maintain that this vagueness is rooted in the lack of a suitable definition of legal power. I shall be arguing for the reduction of the complexity of the definientia by defining legal power as a species of competence. According to the second objection, this non-reductive approach cannot explain the normativity of this kind of rules. Against this approach, it argues that legal powerconferring rules perform a deontic and a definitional function as constitutive rules of legal practice.

KEY WORDS: H.L.A. Hart, competence, practices, presupposition, practical and theoretical points of view of rules

RESUMEN: Este artículo tiene como objetivo explorar dos objeciones planteadas en contra del segundo enfoque defendido por Bulygin en relación con la definición de la naturaleza de las reglas jurídicas que otorgan competencia jurídica. Según la primera, tal enfoque es vago en cuanto a lo que estas reglas jurídicas definen. Esta vaguedad se debe a la falta de una definición adecuada de la competencia jurídica. Defenderé la reducción de la complejidad de definientia definiendo la competencia jurídica como una especie de competencia en sentido general. Según la segunda, este enfoque no reduccionista no puede explicar la normatividad de este tipo de reglas. Contra este enfoque, sostendré que las reglas jurídicas que otorgan competencia desempeñan tanto una función deóntica como una función definitoria en cuanto reglas constitutivas de la práctica jurídica.

PALABRAS CLAVE: H.L.A. Hart, competencia jurídica, prácticas, presuposición, perspectiva teórica y perspectiva práctica de las reglas

\section{Introduction}

Decisions of legal officials, promises, contracts, wills and taxes are considered as some examples of legal power exercises. ${ }^{1}$ Yet despite the relatively widespread agreement among contemporary legal theorists and legal practitioners on what can be described as legal power exercises - numerous questions arise when one asks about the very concept of legal power. As stated by Alexy, this is a clear clue about

${ }^{1}$ Hart has offered a wide characterization of legal power that includes a number of examples. See Hart 1982, p. 194. 
the existence of a philosophical problem. A concept can be used in everyday life; however, when one begins to analyze it, it can become quite doubtful (Alexy 2008, p. 43).

Two prevailing theoretical approaches have dealt with the concept of legal power. On the one hand, it has been argued in well-known theories that legal power is reducible to deontic modalities. Those theories which affirm that legal power-conferring rules are reducible to norms of conduct that are either a kind of duty, or a kind of permission belong to this tendency. Austin's, ${ }^{2}$ Kelsen's, ${ }^{3}$ Ross's, ${ }^{4}$ and Spaak's, ${ }^{5}$ as well as Bentham's, ${ }^{6}$ von Wright's, ${ }^{7}$ Kanger and Kanger's, ${ }^{8}$ and Lindahl's ${ }^{9}$ theories can be considered as examples of this reductionist tendency. On the other hand, those theories that elucidate legal power as a normative social, pragmatic or institutional phenomenon may be identified as examples of an approach that has shown that legal power is not reducible to deontic modalities. In this vein, Hohfeld's, ${ }^{10}$ Hart's, ${ }^{11}$ Raz's ${ }^{12}$ theories, as well as the position of Ruiter ${ }^{13}$ and MacCormick ${ }^{14}$ can be identified as examples of this trend.

Eugenio Bulygin has defended two different approaches in this field. In his early works developed with Carlos Eduardo Alchourrón, he defended a reductionist theory, according to which legal powerconferring rules are a special kind of permissive rules that perform a constitutive function at the same time (Alchourrón and Bulygin 1971,

${ }^{2}$ See Austin 1832, pp. 21-26.

${ }^{3}$ See Kelsen 1992 (1934), §§27-29, pp. 55-57; Kelsen 1987, pp. 1-108; Kelsen 1960, §5 (a), p. 26; §6 (d), pp. 51-52, 58; §6 (e), pp. 55-59; §28 (b), pp. 123-124; §29 (d), 139; §29 (f), p. 144; §30 (a), (c), pp. 150, 156; §34 (b), (c), pp. 198, 204; Kelsen 1945, pp. 60-61; 90-91; 143-144; 270-272; Kelsen 1991 (1979), pp. 25-27; 96-105.

${ }^{4}$ See Ross 2009 (1968), pp. 130-133; Ross 1958, pp. 50-51; 202-213. On the thesis of continuity between the two positions of Ross, see Alexy 2008.

${ }^{5}$ See Spaak 2003; Spaak 2005; Spaak 1994, pp. 166-181.

${ }^{6}$ See Bentham 1970 (1843), p. 22. As stated by Lindahl, "Bentham maintains, consequently, that the concept of power can generally be explicated in terms of permission so far as power to issue mandates is concerned." (Lindahl 1977, p. 202.)

${ }^{7}$ See Von Wright 1963, p. 192.

${ }^{8}$ See Kanger and Kanger 1966. On a comparison between the positions of Hohfeld and Kanger, see Lindahl 1977, pp. 48-63.

${ }^{9}$ See Lindahl 1977, pp. 212-284.

${ }^{10}$ See Hohfeld 1920 (1919), pp. 50-64.

${ }^{11}$ See Hart 2012 (1961), pp. 27-42.

${ }^{12}$ See Raz 1970, pp. 59-102.

${ }^{13}$ See Ruiter 1993, pp. 67-80; 91-102.

${ }^{14}$ See MacCormick 1986, pp. 60-67. 
p. 151). Notwithstanding, by rejecting the normativist position about the nature of law, ${ }^{15}$ these authors have defended a non-reductivist position in order to define legal power-conferring rules. According to this second approach, such rules must be considered constitutive rules —or better said, definitions (Alchourrón and Bulygin 1991, p. 463) - in an exclusive manner, since they do not prescribe any behavior as obligatory, prohibited, or permitted (1991, pp. 462-463). This account has also been defended by Eugenio Bulygin in his article from 1991 titled "On Norms of Competence".

The goal of this paper is to explore two objections raised against Eugenio Bulygin's second approach to the definition of the nature of legal power-conferring rules. According to the first objection, inasmuch as Bulygin's second account maintains that these rules define a variety of heterogeneous phenomena, such an account is vague about what is defined by legal power-conferring rules qua constitutive rules. This problem of vagueness is rooted in the lack of a suitable definition of legal power. In this paper, I shall be arguing for the reduction of the complexity of the definientia through positing a comprehensive concept of legal power which allows one to explain it as a species of competence. According to the second objection, this non-reductive approach cannot explain the normativity of this kind of rules. In other words, the non-reductive approach cannot explain the authoritative feature of legal power. In this paper, I shall be arguing for a dual function of legal power-conferring rules as constitutive rules of legal practice. According to this position, determining the deontic and the definitional function of this kind of rules is a matter of perspective. Unlike the mere activities, the practices are associated with internal normative evaluation standards which are coded by means of rules. These rules govern how to run a practice correctly (Rescorla 2009, p. 101). In this way, from the theoretical point of view, legal power-conferring rules play a definitional role, due to the fact that they are necessary conditions for the identification of the practice. In contrast, from the practical point of view, legal powerconferring rules carry out a deontic function, due to the fact that they are necessary conditions for achieving the aims associated with the practice.

Our inquiry will be divided into three parts. The first part will deal with Bulygin's theory of legal power-conferring rules. The second part will be devoted to the analyses of the problem of vagueness and

\footnotetext{
${ }^{15}$ See Alchourrón and Bulygin 1991 (1983), p. 463. The non-normativist tenet was already defended in Alchourrón and Bulygin 1971, pp. 58-61, 64.
} 
the exposition of a method for the reduction of the complexity of definientia. The third part addresses the problem of the normativity of the legal power-conferring rules qua definitions.

\section{Eugenio Bulygin's Theory of Legal Power-Conferring Rules}

In his theory, von Wright coined the name normative action in order to refer to a peculiar mode of action by virtue of which an authority "orders, permits, or prohibits certain subjects to do certain things on certain occasions" (1963, p. 75). This peculiar mode of action is ruled by a special kind of norms which have been termed "norms of higher order" (p. 190). According to von Wright, subjects of norms of higher order are themselves authorities of norms of lower order (p. 192). The norms belonging to a higher order must be distinguished from those whose contents are other than normative actions, i.e. norms of the first order (p. 191). Whilst among norms of the first order commands and prohibitions hold the most prominent position, in norms of higher order permissions are of peculiar interest and importance (p. 192). In this vein, according to von Wright's account, legal power-conferring rules are norms of higher order which permit a certain authority to issue norms of a certain content (p. 192).

According to Alchourrón and Bulygin, the main interest of jurists lies in discovering the solutions that law provides for certain cases (1971, p. 68). This activity amounts to "the determination of the normative consequences of a set of legal sentences for a certain problem or topic" (p. 68). This determination involves "the construction of an axiomatic system, adopting these [legal] sentences as axioms" (p. 68). In order to achieve that construction, jurists must define the criteria that will be used to identify those sentences (p. 68). ${ }^{16}$ These identification criteria define the notion of a valid legal sentence (p. 73) by setting out which requirements a legal statement must meet to be valid (p. 72). For the reason that these identification criteria are conceptual rules - that is, they merely regulate the use of the concept of validity - (p. 73) they must be distinguished from

\footnotetext{
${ }^{16}$ According to Alchourrón and Bulygin, the determination of the normative consequences of a set of legal sentences for a certain problem or topic "presupposes the existence of certain elements which are the starting point for the systematization. These elements are: (1) a problem or a group of problems (a topic), whose regulation by the law is of interest to the jurist; (2) a set of legal sentences, relevant to the topic in question; (3) a set of rules of inference used by the jurist in the derivation of the consequences." These "three elements (topic, legal sentences and rules of inference) determine the content of a normative system and the task of jurists consists in formulating it explicitly and, eventually, in reorganizing it" (1971, p. 70).
} 
those norms which establish that an action is obligatory, forbidden or permitted - that is, from norms of conduct (Alchourrón and Bulygin 1991, pp. 462-463). Alchourrón and Bulygin abandon a certain legal positivist tradition, which identifies the validity criteria of a legal system with its norms of competence ${ }^{17}$ - rectius: legal power-conferring rules (1971, p. 73, n. 2)- ${ }^{18}$ by maintaining that the identification criteria must not be confused with such norms, since, in contrast to those criteria, they must be considered as a special class of norms of conduct which "[permit] the creation of new norms" (1971, p. 73).

For Alchourrón and Bulygin, the centralization of the function of jurisdiction in the hands of specialized officials is a plausible reason for the existence of two normative systems which run parallel but that are interdependent (1971, p. 148). Along with a primary system —or better said, a subject system - which is made up by norms which regulate the behavior of the subjects of law, there is a secondary system — or better said, a judge system - which is comprised of norms which regulate the behavior of judges and other jurisdictional organs (p. 148). These latter norms may be either norms of competence or norms which establish obligations and prohibitions for the judges (p. 151). Based on von Wright's theory, Alchourrón and Bulygin affirm that norms of competence are "norms of conduct for the judges, if we regard them as permissive norms establishing the permission to perform certain acts in certain circumstances" (p. 151). Notwithstanding, they argue that these permissive norms are a special kind since, at the same time, they are constitutive of judicial authority. In fact, "nobody becomes a judge except on account of a norm of competence and to the degree and extent that this norm

${ }^{17}$ See, among others, Kelsen 1960, at $\$ 34$ (b)-(c), pp. 198-204. According to Paulson, "[a]n explication of gradations within the legal norm is facilitated by appeal to two notions in Kelsen's work: first, the familiar juridico-positivist view of legal validity as membership, and second, as already noted, the ex ante and ex post or 'before issuance' and 'after issuance' perspectives on the legal norm. Accordingly, a legal norm will be valid only if it belongs to the legal system, and membership in the legal system is manifest only if the norm in question can be traced back to the applicable higher-level norm. This higher-level norm, addressed prior to issuance of the norm in question to norms of that kind, is an empowering norm; after the fact of issuance the empowering norm serves - vis-à-vis the issued norm- as a criterion for identifying this norm as legally valid" (Paulson 2000, p. 153).

${ }^{18}$ As stated by Bulygin and Alexy, a conspicuous lack of agreement on terminology characterizes the treatment of the topic. Whilst Anglo-American writers usually use the term "power-conferring rules", writers from the Roman law tradition customarily use the term "competence norms". In what follows, both of these terms will be used synonymously. (See Bulygin 1991, pp. 201-202; Alexy 2008, p. 43.) 
specifies" (p. 151). These norms "are part of the meaning of the term "judge" " (p. 151).

Various criticisms have been raised against the position that posits the reduction of legal power-conferring rules to permissive rules. ${ }^{19}$ On the one hand, Makinson has sharply pointed out that the difference between these kinds of rules lies in the necessary constitutive feature of the former. Indeed, according to him,

[i]f a person does something that is not permitted, then the action is done, although it may render the person liable to punishment. On the other hand, if a person tries, say, to celebrate a marriage or issue a passport without having the power to do so, then we say that he has not in fact celebrated a marriage or issued a passport (for emphasis: has not issued a valid passport) but has only gone through the motions or given the appearance of doing so. (Makinson 1986, p. 411)

On the other hand, based also on the constitutive nature of the legal power-conferring rules, Makinson has recognized a structural difference between legal power and permission that has been less noticed. Although it makes perfectly good sense to say, that a person has permission not to do something, it is very strange to say that someone has the legal power not to perform it (1986, p. 412).

But even more importantly, Bulygin himself has accepted that "[t]he idea that competence norms are essentially permissive is difficult to reconcile with legal practice" (Bulygin 1991, p. 205). ${ }^{20}$ In fact, against von Wright's position, Bulygin has maintained that "[i]f competence norms are permissions, then a prohibition to make use of the power conferred by such norms would generate a contradiction, but this is not how such situations are in fact treated by jurists" (1991, p. 206). Indeed, legal practice shows that a main argument, which can be raised against the reduction of legal power-conferring rules to permissive rules, reveals that while there is a normative conflict between a permissive rule and a prohibitive rule referring to the same action, a normative conflict between a legal power-conferring rule and a prohibitive rule to exercise such legal power cannot take

\footnotetext{
${ }^{19}$ The roots of the discussion about the problem of the distinction between legal power — rechtliches können - and permission — dürfen - can be traced back to the German jurisprudence of 19th century. See, among others, von Brinz 1873, p. 211; Jellinek 1963 (1905), p. 48, note 1. In the American jurisprudence see, inter alia, Hohfeld 1920, p. 58.

${ }^{20}$ On the relation between Kompetenz and Erlaubnis, see Alexy 1994 (1985), pp. 212-214.
} 
place, given that the constitutive nature of legal power-conferring rules entails that every rule that prohibits one from exercising the legal power presupposes a rule that ascribes it. ${ }^{21}$

As is well known, one of the fundamental tenets of Alchourrón and Bulygin's theory is the rejection of the normativist position about the nature of law. ${ }^{22}$ Based on this tenet, Alchourrón and Bulygin abandoned the reductive thesis that they had defended until their article from 1983 titled "Definitions and Norms" (1991 (1983)). According to their second approach, legal power-conferring rules are definitions, or better said, conceptual rules - that is, rules that "merely regulate the use of a concept (or a term)" (Alchourrón and Bulygin 1971, p. 73). This account has also been defended by Eugenio Bulygin in his article from 1991 titled "On Norms of Competence".

In accordance with this second approach, legal power-conferring rules cannot be reducible to norms of conduct, due to the fact that they only "define patterns of behavior, which do not exist outside these rules" (Bulygin 1991, p. 211). In other words, legal powerconferring rules must be considered conceptual rules or definitions in an exclusive manner (p. 211), since they do not prescribe any behavior as obligatory, prohibited, or permitted (p. 211). This second position of Bulygin is based on Searle's account, according to which while regulative rules regulate an activity whose existence is logically independent of the rules, constitutive rules constitute an activity the existence of which is logically dependent on the rules (Searle 2009 (1969), p. 34). In this way, Searle affirms that whereas regulative rules characteristically take the form of, or can be paraphrased as imperatives, constitutive rules can be construed as analytic by means of the form "X counts as $\mathrm{Y}$ in context C" (p. 34). As stated by Bulygin,

${ }^{21}$ As we shall see, based on the premise that, from the theoretical point of view, the definition of the participants is a necessary condition for every single practice, and that such a definition amounts to the ascription of the ability of following the rules that constitute and regulate such a practice to certain agents, it is possible to distinguish between legal power-conferring rules and procedural rules of legal power as necessary normative conditions for the exercise of legal power. The first kind of rules ascribe the ability to follow certain legal rules in order to create legal norms - or legal effects - to an agent. The second kind of rules prescribe that the exercise of legal power is obligatory, prohibited, or permitted. Given that if there is not a competent agent, then procedural rules of legal power cannot be followed, and, moreover, that if there is no rule that ascribes the ability to follow such procedural rules to someone, then there is no competent agent, therefore every single procedural rule of legal power presupposes a legal power-conferring rule, which constitutes a competent agent in order to follow it.

${ }^{22}$ See Alchourrón and Bulygin 1991, p. 463. The non-normativist tenet was already defended in Alchourrón and Bulygin 1971, pp. 58-61, 64. 
a non-reductive definition of legal power-conferring rules provides a suitable conceptual tool in order to grasp the rather obscure concept of "rechtliches Können" (1991, p. 215).

\section{The Problem of Vagueness}

Despite its virtues, the non-reductive approach defended by Bulygin is not without problems. Two important criticisms may be raised against it. First, as stated by Ferrer Beltrán (2000, pp. 97-99), Bulygin's account from 1991 (p. 215) is not clear about what is defined by legal power-conferring rules qua constitutive rules. According to Ferrer Beltrán's objection, Bulygin posited four possible candidates of definientia. Legal power-conferring rules could define not only the form of entering into a contract, or a will in order to make it valid, but also, in a more general way, some kind of legally relevant behaviors. Legal power-conferring rules could define not only the concept of legislator and make legislating possible, but also, in a more general way, what a contract, a promise or a will is. This vagueness shows one of the biggest obstacles that must face anyone who addresses the problem of the definition of legal power-conferring rules: The problem of the complexity of the definientia. This problem is rooted in the lack of a suitable definition of legal power.

I shall be arguing for the reduction of the complexity of the definientia through positing a comprehensive concept of legal power that allows one to explain it as a species of competence. ${ }^{23}$ As Ross has pointed out, the normative conditions for the exercise of legal power

usually fall into three groups: (1) those which prescribe what person (or persons) is qualified to perform the act which creates the norm (personal competence); (2) those which prescribe the procedure to be followed (procedural competence); and (3) conditions which prescribe the possible scope of the created norm with regard to its subject, situation, and theme (substantial competence). (Ross 2009, p. 130)

${ }^{23}$ This determination of the proximate genus of legal power can explain the reason why the conspicuous lack of agreement on terminology that characterizes the treatment of the topic has been compatible with the accepted practice of use as synonymous of the terms "legal competence" and "legal power" within the AngloAmerican, Scandinavian and Roman law tradition. (See Lindahl 1977, p. 194; Spaak 2005; Bulygin 1991, pp. 201-202; Alexy 2008, p. 43.) For a very different perspective about the relation between "legal competence" and "legal power", see Kurki 2017. 
Although Ross has stated that these three groups of conditions are necessary for the exercise of legal power, procedural and substantial competence presuppose that the competence has been ascribed at least to a person. In this sense, personal competence has an analytic priority over the other two necessary conditions. ${ }^{24}$

Based on this analytic priority, competence can be considered as a lexical attributive concept. As stated by Werning based on Millikan, a basic distinction is that between attributive and substance concepts.

Attributive concepts represent features of objects that are volatile in the sense that one and the same object can fall under different attributive concepts at different times: An object may, e.g., change its color, size, or speed, but still continues to exist. [Blue] thus is a paradigmatic attributive concept. Substance concepts, in contrast, are governed by the identity conditions of objects: A mug ceases to exist when it no longer falls under the substance concept [mug], say, because it has been shattered. Substance concepts serve to re-identify things over time in spite of their contingent changes of attributes and so allow us to gather, store and update information in a systematic and enduring way. (Werning 2008, p. 70)

The question thus becomes, what is attributed to an agent by means of the concept of competence ${ }^{25}$ The ability ${ }^{26}$ to follow rules is attributed to an agent by means of the concept of competence, that is, the practical possibility ${ }^{27}$ of behaving as a result of understanding

${ }^{24}$ As stated by Davies, "analytical priority, is priority in the order of philosophical analysis or elucidation. To say that $X$ is analytically prior to $Y$ is to say that key notions in the study of $Y$ can be analysed or elucidated in terms of key notions in the study of $X$, while the analysis or elucidation of the $X$ notions does not have to advert to the $Y$ notions" (Davies 1998, p. 227).

${ }^{25}$ The use of the word "agent" aims at highlighting the inherent relationship between "competence" and "action". As stated by Tomann, "Gekonnt werde Handlungen oder Handlungstypen und die Handlungen, die eine Person -im Folgenden als Agent bezeichnet - tatsächlich ausführt, stehen in Beziehung zu seinen Fähigkeiten" (Tomann 2010, p. 1).

${ }^{26}$ In this vein, as Austin has held, ability and opportunity are the components of what is expressed by the verb "can" (Austin 1966 (1956), p. 315. See Gardner 2013, p. 67). On a unified analysis of modals like "must" and "can" based on Lewis" contributions see Kratzer 2012, esp. pp. 4-20.)

${ }^{27}$ In this sense, according to Peirce, " $\mathrm{t}$ ] he information considered may be our actual information. In that case, we may speak of what is possible, necessary, or contingent, for the present. Or it may be some hypothetical state of knowledge. Imagining ourselves to be thoroughly acquainted with all the laws of nature and their consequences, but to be ignorant of all particular facts, what we should then not know not to be true is said to be physically possible; and the phrase physically 
and applying rules (Williams 2010, p. 192) —or in other words, the practical possibility to engage with reasons. ${ }^{28}$ Since this rule-obeying behavior implies knowledge ${ }^{29}$ and intention (Baker and Hacker 1984, p. 299), it can be distinguished from that behavior that as a matter of fact conforms to some rule or instantiates a law in a causally determined way (p. 192). ${ }^{30}$

necessary has an analogous meaning. If we imagine ourselves to know what the resources of men are, but not what their dispositions and desires are, what we do not know will not be done is said to be practically possible; and the phrase practically necessary bears an analogous signification. Thus, the possible varies its meaning continually. We speak of things mathematically and metaphysically possible, meaning states of things which the most perfect mathematician or metaphysician does not qua mathematician or metaphysician know not to be true" <CP 4.66> (Peirce 1933 (1893), §3).

${ }^{28}$ The use of this expression can be found in Gardner 2013, pp. 68-71.

${ }^{29}$ As is well known, this inextricable link between competence and knowledge is the very heart for the distinction between competence ("the speaker-hearer's knowledge of his language") and performance ("the actual use of language in concrete situations") that has become the cornerstone for the construction of Chomsky's linguistic theory. (Chomsky 1965, p. 4. On linguistic competence and generative grammar, see, inter alia, Chomsky 1966, 1972, and 1980.)

${ }^{30}$ As expressed elsewhere (see Villa Rosas 2015, p. 53), rule-following behavior implies acknowledgment of the rule as an attitude toward it that mediates its normative coercion. As reminded by Brandom, for Kant the distinction between facts and rules is itself not a factual but a normative difference (Brandom 1998, p. 58). This distinction is that between acting according to rules and acting according to conceptions of rules. Thus, according to Brandom, "[w] hat is distinctive about us as normative creatures is the way in which we are subject to norms (for Kant, in the form of rules). As natural beings, we act according to rules. As rational beings, we act according to our conceptions of rules. It is not being bound by necessity, acting according to rules, that sets us apart; it is being bound not just by natural but by rational necessity" (p. 30). According to Brandom, the Kantian practical philosophy — and particularly his Kritik der praktischen Vernunft - is devoted to examining these two different ways of relating to rules (p. 30). With regard to the particular human way of relating to them, Kant's position explains two key features. On the one hand, his position clarifies the link with the rules by means of normative modalities in terms of "ought" (p. 31). This explanation allows one to distinguish between causal relations, and obedience relations. The first ones refer to relations between natural entities. The second ones refer to relations between intentional agents. On the other hand, his position illustrates the human link with the rules through the analysis of normative coercion (p. 31). This second approach refers to the distinction between motivation and moral obligation. According to Brandom's Kantian interpretation, with regard to us - as humans - the normative coercion is mediated by our attitude toward the rules. In this vein, the tension involving the distinction between motivation and moral obligation is settled by means of the conclusion according to which "[w] hat makes us act as we do is not the rule or norm itself but our acknowledgment of it". According to the Enlightenment tradition, our own acknowledgment of a rule is "the source of its authority over us" (p. 51). 
Notwithstanding, given that knowledge and intention are mental states which are only accessible by the subject who is experiencing them, the actual use of a rule is the only warrant for the fact that it is understood (Williams 2007, p. 74). In this way, the ability to follow a rule has to be understood not as a hidden mental state or process ${ }^{31}$ but as a know-how that has to be displayed in actions (Medina 2002, p. 179). ${ }^{32}$ Thus, according to Kripke:

Our entire lives depend [...] on the 'game' of attributing to others the mastery of certain concepts or rules, thereby showing that we expect them to behave as we do. This expectation is not infallibly fulfilled. It

In this way, Brandom has pointed out, "our normative statuses such as obligation are instituted by our normative attitudes" (p. 51). Brandom has explained that this statement should not be understood in the sense of the normative status effect upon our everyday behavior, but it should be understood according to the fact that we are exposed to a moral judgement under the rule that expresses its rational necessity (pp. 51-52). Notwithstanding, once we endorse a rule - Brandom argues - "it is not up to us what it demands - there is some fact of the matter as to what we have thereby obliged ourselves to do" (p. 52).

${ }^{31}$ Chomsky has defined his own linguistic theory as "mentalistic, since it is concerned with discovering a mental reality underlying actual behavior." (Chomsky 1965, p. 4.) Against his position, Baker and Hacker have stated, "[c]ompetence, occasionally conceived as a mental organ, is held to determine performance (albeit with hiccups en route) as a causal mechanism determines the visible motion of a machine. This is absurd! [...] Since rules can be said to have a structure (because logical relations obtain between rules, their parts and their applications), the linguist attributes the structure of his hypothesized rules to the mythical cognitive state, to the language faculty and, finally, to the brain. This muddle does explain one feature of his story, namely his inclination to view linguistic performance as flowing causally from competence. For if the language faculty is a set of rules, then since rules determine their applications, surely the language faculty determines the linguistic performance! But, of course, it does not. For rules determine (logically) what is to count as correct applications of them, i.e. we use rules (though not 'hidden' ones) together with a method of projection to fix what is to be called following this 'rule'. But the rules do not causally determine what we actually do, rather they normatively determine whether what we do is correct or not. A neural or mental state on the other hand could only causally determine a consequence, not normatively or logically. It could not determine whether what is done is right, nor could it suffice to render behaviour an instance of rule-following at all. The linguist fails to grasp the categorical distinction between a state and an ability (power or potentiality). Consequently, he misconstrues the conceptual relationship between an ability and its manifestations. These confusions are then multiplied by his failure correctly to apprehend the relation of rule-governed activities to the rules that govern them" (Baker and Hacker 1984, pp. 281-283).

${ }^{32}$ As is know, this crucial point has been called the "Manifestation Argument". (See Wittgenstein 1958, Philosophical Investigations, $§ \S 146-171$.$) On the difference$ between knowing how and knowing that, see the seminal presentation of Ryle 2009 (1949), esp. pp. 14-48. 
places a substantive restriction on the behavior of each individual, and is not compatible with just any behavior he may choose. [...] We can restate this in terms of a device that has been common in philosophy, inversion of a conditional. (Kripke 1982, p. 93)

As stated by Riesenfeld based on Wittgenstein's view of rules, “[a]n inverted conditional retains the causal structure of the original conditional but reverses the order of 'cause' and 'effect'. [...] 'We do not say that $12+7=19$ and the like because we all grasp the concept of addition; we say we all grasp the concept of addition because we all say $12+7=19$ and the like" (Riesenfeld 2010, p. 46).

In this way, the answer about the normative nature of the starting point of our practices ${ }^{33}$ must be found in the mutual ascription of competence by means of which subjects achieve their own constitutive status as normative entities, that is, as agents capable of making commitments and being accountable (Villa Rosas 2015, p. 55). Indeed, from the practical point of view, every single practice requires that each participant should acknowledge with respect to others what he acknowledges of himself, that is, the ability to follow rules (p. 55). And hence, from the theoretical point of view, the definition of the participants —as a necessary condition for every single practiceamounts to the ascription of the ability of following the rules that constitute and regulate such a practice to certain agents. In this vein, every single rule presupposes the ascription of the ability to follow it to an agent —or in other words, every single rule presupposes a rule that constitutes a competent agent. ${ }^{34}$

${ }^{33}$ See Brandom 1998, pp. 170-171.

${ }^{34}$ This is our paradox: if every single rule presupposes a rule that constitutes a competent agent, then the rule that constitutes a competent agent presupposes a rule that constitutes a competent agent. This refinement amounts seemingly to infinite regress that can only be avoided by positing a fundamental competence rule that prescribes a universal commitment of acknowledgement. In fact, according to the inferentialist theory of meaning, the statement meaning depends on a conceptual practice by means of which the statement meaning is attributed (Brandom 1998, pp. 142-143). This fundamental competence rule is a constitutive rule of this fundamental conceptual practice - i.e. the practice of giving and asking for reasons - on which all other practice depends and in which assertion is a fundamental linguistic activity. Indeed, as expressed elsewhere, "[Brandom] has noted that the practice of giving and asking for reasons is made of deontic statutes which govern the behavior of the participants in this privileged practice. These deontic statutes correspond to doxastic commitments and entitlements. The doxastic commitments are distinguished by the fact that they can be required by other participants who are entitled to do it. In this way, a consequential relationship is generated by means of changes in the deontic statutes of each participant. Each change is brought about as a result 
Given that a rule is a kind of norm (Alexy 1994, pp. 71-104), that a norm is the meaning of a normative statement, and that a normative statement expresses that something is required, permitted, or prohibited (1994, pp. 39-53), the ascription of the ability to follow a normative content to an agent is a speaker's existential presupposition associated with the expression of deontic modalities as conventional specific triggers. ${ }^{35}$ Although premised on a prescriptive conception of norms, by analyzing the relation between "ought" and "can", Hare has noticed that their relation is

analogous to that Mr. Strawson has claimed to exist between the statement that the King of France is wise, and the statement that there is a King of France. If there is no King of France, then the question whether the King of France is wise does not arise. And so, by saying that the King of France is wise, we give our hearers to understand that we think, at least, that the question arises to which this is one possible answer, and that, accordingly, there is a King of France. And similarly, if we say that somebody ought to do a certain thing, and "ought" has its full (i.e. universally prescriptive) force, then we give our hearers to understand that we think that the question arises to which this is a possible answer, which it would not, unless the person in question were able to do the acts referred to. (Hare 1963, pp. 53-54)

At this point, we need to distinguish between the analysis of the context of ascriptions of responsibility - which is closely related to the problem of free will - and the analysis of meaning of normative statements. Whilst the first analysis deals with the relation between the agent and the rule, the second analysis addresses the propositional

of an assertion performance [...]. The answer about the normative nature of the starting point of our discursive practices lies in the mutual acknowledgement by means of which subjects achieve their own constitutive status as normative entities. From the first person perspective, this acknowledgment involves a subject's universal doxastic commitment — as a member of the linguistic community - to acknowledge others as capable of making commitments and being accountable. In other words, this universal commitment means that each linguistic community member should acknowledge with respect to others what he acknowledges of himself, that is, in general, the ability to follow rules, and specifically, the ability to follow linguistic rules - rectius: linguistic competence. In this way, with regard to the privileged speech act of assertion, the acknowledgment commitment implies the addressee's doxastic commitment of assuming that the speaker is able to meet the rule of knowledge - as assertion's singular constitutive rule - when the speaker performs an assertion" (Villa Rosas 2015, p. 55). I am very grateful to Natalia Scavuzzo for her help in thinking about this issue.

${ }^{35}$ On presupposition in general, see Beaver and Geurts 2014. 
content of normative statements as units of meaning. ${ }^{36}$ Notwithstanding, these analyses are closely interwoven.

On the one hand, the analysis of the ascription of responsibility takes for granted that there is a normative content that could be followed by every agent who is under the conditions required by such content - Tatbestand - and accordingly, it may be based on the requirement that only such agents who were able to follow this content can be blamed. This argument is closely linked to the Principle of Alternate Possibilities (PAP), according to which "[a]n agent is morally blameworthy for what she has done only if she could have done otherwise" - as is well known, Frankfurt famously argued that this maxim is false (Frankfurt 1998 (1969), p. 1). ${ }^{37}$ However, as stated by Stern, this argument, when accepted, shows merely that "blame implies can" (Stern 2004, p. 46).

On the other hand, the analysis of the ascription of responsibility requires the analysis of the propositional content of a normative statement as a unit of meaning. Indeed, ascribing responsibility to an agent entails making explicit the general presupposition of the ascription of the ability to follow a normative content in relation to this particular agent - which involves the subsumption of the rule referred to by the normative statement. The analysis of the relation between the normative content and such a presupposition leads to the analysis of the relation between "ought" and "can". As stated by Gardner, "[t]he thesis that "ought" implies "can' [...] is often traced back to Kant. The attribution is correct but misleading. Those who invoke ['ought' implies 'can'] today typically argue that, because $A$ lacks the ability to $\Phi$, it cannot be the case that $A$ ought to $\Phi$. What one ought to do cannot be established without first establishing what one can do" (Gardner 2013, p. 63). Indeed, since this interpretation of the maxim " ought' implies "can" " entails positing that "can" is a necessary condition for "ought", 38 it implies a form of a naturalistic fallacy, in the sense, that factual circumstances referring to what the subject "can" determine what the subject "ought". ${ }^{39}$ Nevertheless, as

${ }^{36}$ A similar distinction has been pointed out by Stern, see Stern 2004, p. 57.

${ }^{37}$ On the Principle of Alternate Possibilities, see, for instance, Copp 2008, Yaffe 1999, and Stern 2004, p. 46.

${ }^{38}$ See Timmermann 2003, p. 113.

${ }^{39}$ As stated by Timmermann, “[d]as, was am Prinzip 'Sollen impliziert Können” in der Ethik hauptsächlich interessiert, ist also die Umkehrung bei moralischen Zweifelsfällen, die man auch folgendermaßen formulieren könnte: Du kannst es nicht tun, also ist es unmöglich, daß du es tun sollst. Auf gut Leteinisch: ultra posse nemo obligatur" (2003, p. 114). On the criticisms against this interpretation of the 
affirmed by Gardner, "Kant invoked ['ought' implies 'can'] to argue in the opposite direction. His thought was that, because $A$ ought to $\Phi$, it cannot be the case that $A$ lacks the ability to $\Phi . "$ In fact,

in so far as Kant thinks that nothing can prevent the moral law commanding us, he does so because his conception of our agency is such that he holds us to be essentially capable of acting as right requires, not because our capacities as human agents naturalistically conceived put limits on what the moral law can comprise, so that no such gap can arise based on his conception of us qua exemplary agents, and not merely on his conception of "ought implies can". (Stern 2004, p. 57)

In this vein, a Kantian interpretation of our ability to follow rules -i.e. competence - must be based "also nicht nach der empirischen Kenntniß, die wir vom Menschen haben, wie sie sind, sondern nach der rationalen, wie sie der Idee der Menschheit gemäß sein sollen" (<AAVI: 405> (Kant 1797, vol. VI, p. 404)). In other words, as stated by Kripke, "what is important here is that the notion of 'competence' is itself not a dispositional notion. It is normative, not descriptive" (1982, pp. 30-31, n. 22).

For the sake of clarity, let us imagine two strangers who want to start a game of chess. The one who is playing with the white pieces must ascribe the ability to follow the rules of chess to the one who is playing with the black pieces and vice versa. Moreover, the rules of chess must not be adapted to the actual abilities of the players of this concrete game but, on the contrary, every single rule of chess presupposes the ability that every single player must have in order to follow it. It is precisely the ascription of the ability to follow the rules of chess as a whole that allows a third person, who is looking on these agents taking part in the game, to define them as chess players.

Accordingly, given that the concept of grammar presupposes the concept of competence, this latter concept can also account for the depth of legal practice. In this way, since the multi-layered character of competence extends over multiple levels of abstraction, it may account for the continuity between semantics, pragmatics, practical reason, and law. ${ }^{40}$

maxim " "ought' implies 'can"”, see, among others, Sinnott-Armstrong 1984, and Strocker 1971.

${ }^{40}$ On this virtue of the concept of discourse grammar see Pavlakos 2007, p. 84. 
In this vein, it is possible at this point to distinguish between legal competence in a broad sense and legal competence in a narrow sense - or legal power. By means of the concept of legal competence in a broad sense is attributed the ability to follow some kind of rules that we called legal rules that is, the practical possibility of behaving as a result of understanding and applying legal rules - to an agent. ${ }^{41}$ Legal power is a special case of legal competence; more specifically as held by Ross, legal power is "the legally established ability to create legal norms (or legal effects) through and in accordance with enunciations to this effect" (Ross 2009, p. 130). ${ }^{42}$

${ }^{41}$ I should like to turn to the widespread use of the term "competence" and "competency" in the legal purview of United States (see e.g. adjudicative competence; competency to stand trial: Dusky v. United States, 362 U.S. 402 (1960); Jackson v. Indiana, 406 U.S. 715 (1972); Drope v. Missouri, 420 U.S. 162 (1975); Estelle v. Smith, 451 U.S. 454 (1981); Ford v. Wainwright, 477 U.S. 399 (1986); Rivers v. Katz, 495, N.E. 2d 337 (N.Y. 1986); Washington v. Harper, 494 U.S. 210 (1990); Foucha v. Lousiana, 504 U.S. 71 (1992); Riggins v. Nevada, 504 U.S. 127 (1992); Godínez v. Moral, 509 U.S. 389 (1993); Cooper v. Oklahoma, 517 U.S. 348 (1996); Stewart v. Martinez-Villareal, 523, U.S. 637 (1998); Sell v. United States, 539 U.S. 166 (2003); Panetti v. Qarterman, 551 U.S. 930 (2007)) by comparison with the more widespread use of the term "capacity" in the English and Continental legal purview. As stated by Skegg, "[g]iven the current dominance of the United States in medico-legal discourse and biomedical ethics, it is not surprising that the term 'competence' is now very frequently used in (for example) Australia and New Zealand. However references to capacity continue to occur in many contexts" (Skegg 2011, p. 166).

${ }^{42}$ Regarding this definition, Klatt has held based on Alexy's analysis of Ross's contribution that this term - legal power- is characterized by the genus proximum ability or possibility as well as three differentiae specificae. The first differentia specifica is the characterization of legal power as a normative possibility. Legal powers presuppose norms that justify them, which are constitutive for them. Accordingly, Ross describes legal power as a normative modality. The second distinguishing feature is that of disposability (Disposivität). Legal power is the possibility of creating legal norms or legal effects. More generally, legal power is the ability to change a legal position, that is, to dispose of it (Klatt 2014, pp. 34-35). Given that the ability to change a legal position through the exercise of legal power is a normative possibility - that is, that legal power is constituted and regulated by legal norms - the possibility to change a legal position as exercise of legal power either through intentional and negligent damage - Schuldfähigkeit - or by means of committing crimes - Deliksfähigkeit - would imply that the norms that regulate the exercise of legal power lay down such a possibility - that is, that the procedural rules of legal power allow unlawful acts. In this way, it is patently obvious that -in principle - although a legal position can be changed either by damage or by committing a crime, this possibility cannot be held as a case of exercise of legal power. Nevertheless, reacting against a large tradition of writings, Kurki has argued for the alternative (see Kurki 2017). 
In fact, changing a legal position may ${ }^{43}$ involve, firstly, a normative status defined by a legal rule ascribing to a person the ability to follow certain rules (rectius: personal competence), and secondly, the fact that this person performed a special kind of act according to the rules that regulate her ascribed ability to follow such rules (rectius: procedural competence) (Spaak 1994, p. 10). In this sense, it is possible to distinguish between legal power-conferring rules and procedural rules of legal power as necessary normative conditions for the exercise of legal power. ${ }^{44}$ Whilst the former rules ascribe to

${ }^{43}$ Indeed, a legal position can be changed by acts that cannot be described as exercises of legal power. (See, inter alia, Hohfeld 1920, pp. 50-51; Alexy 2008, p. 48.)

${ }^{44}$ In this vein, according to Ross, "[the] power or competence of a person must be distinguished both from a liberty to exercise his powers as he pleases (but only, of course, intra vires) and from a duty to exercise it along certain lines. If there is such a duty there exists a norm of conduct, whose theme is the way in which the competent person is to exercise his power" (2009 (1968), p. 131). As expressed above, given that if there is not a competent agent, then procedural rules of legal power cannot be followed, and, moreover, that if there is not any rule that ascribes the ability to follow such procedural rules to someone, then there is not a competent agent, therefore every single procedural rule of legal power presupposes a legal powerconferring rule, which constitutes a competent agent in order to follow it. Firstly, as an example of the relation between legal power-conferring rules and procedural rules of legal power which impose duties, let us take the legal power whose exercise entails heteronomous effects. As is known, this kind of legal power characterizes public authorities. According to Ross, "there are the rules of competence that create what we call a public authority. They have the following features. They create a power only for certain qualified persons. The required qualification consists in a designation in accordance with certain rules of law: in Denmark, Ministers have their power because of their nomination according to Article 14 of the Constitution, members of Parliament because of their election according to the Polling Act, and the King because of his hereditary right to the throne according to the Act of Succession. The substance of this power is a capacity to create rules that bind others (statutory enactments, judgments, administrative acts). The power is not granted with a view to its being used by the competent person freely and at his convenience. Its exercise is a duty, a public office in the widest sense, and when exercised it is a duty to use the power in an unprejudiced and impartial manner, for the furtherance of certain social purposes. These duties are more than merely moral duties; they are hedged in by sanctions and controls of various kinds. The power's social function is to serve the interest of the community - what is called the "common weal'" (2009 (1968), p. 133). Secondly, regarding the legal power whose exercise entails autonomous effects, which characterizes private law persons, the general requirement of contractual capacity - Geschäftsfähigkeit - that is presupposed by the rules of special contract law serves as an example of the relation between legal powerconferring rules and procedural rules of legal power which impose anankastic duties. (On exercises of legal power with heteronomous and autonomous effects, see Spaak 1994, pp. 129-134.) 
a person the ability and disposition to follow certain rules in order to create legal norms - or legal effects - the latter rules regulate the use of this ability. ${ }^{45}$ This common intuition allows the distinction between the creation and the exercise of legal power. Indeed, as Lindahl suggests, having legal power means having the practical possibility to change legal positions, no matter if this possibility is never exercised (Lindahl 1977, pp. 206-210). Given that if there is not a competent agent, then procedural rules of legal power cannot be followed, and, moreover, that if there is not any rule that ascribes the ability to follow such procedural rules to someone, then there is not a competent agent, therefore every single procedural rule of legal power presupposes a legal power-conferring rule, which constitutes a competent agent in order to follow it.

\section{The Lack of Explanation of Normativity}

According to the second objection raised against Eugenio Bulygin's second approach to the definition of the nature of legal powerconferring rules, such an approach cannot explain their normativity. ${ }^{46}$ In other words, the non-reductive approach cannot explain the authoritative feature of legal power. This criticism is related to the

${ }^{45} \mathrm{It}$ is worth noting that this distinction should not be confuse with that referring to norm-creating and regulative competence. While the distinction above mentioned refers to kinds of rules of legal power, this second one refers to rules as exercises of legal power. In this vein, for instance Raz distinguishes between the (norm-creating) power to create, repeal, or modify laws (and norms) and the (regulative) power to regulate the application of laws (and norms). (Raz 1972, pp. 81-82. On the distinction between norm-creating and regulative competence as forms of competence, see Spaak 1994, pp. 134-143.)

${ }^{46}$ In a very enlightening paper, Postema has stated that one of the fundamental and intuitively plausible theses that dominates philosophical reflection on the nature of law and adjudication is the normativity thesis, according to which "[l]aw is a form of practical reasoning; like morality and prudence, it defines a general framework for practical reasoning. We understand law only if we understand how it is that laws give members of a community, officials and law-subjects alike, reasons for acting. Thus any adequate general theory of law must give a satisfactory account of the normative (reason-giving) character of law and must relate the framework of practical reasoning defined by law to the framework of morality and prudence" (Postema 1982, p. 165). As we shall see, a strong form of the normativity thesis implies positing that only duty-imposing norms are genuine norms in the sense that they give complete reasons for action. (See Spaak 2003) In this vein, the second objection raised against Eugenio Bulygin's second approach to the definition of the nature of legal power-conferring rules can be understood as follows: If legal powerconferring rules must be considered conceptual rules or definitions in an exclusive manner they cannot give members of a community, officials and law-subjects alike any reasons for acting, therefore they cannot be considered genuine legal norms. 
problem of the relation between constitutive and regulative rules. ${ }^{47}$ As a matter of fact, although authors like Searle and von Wright have not ruled out the prescriptive function of constitutive rules, others have claimed that these rules do not play any motivational role over the agents, but rather a restricted doxastic role with regard to the observer. ${ }^{48}$ In its stronger form, the objection identifies normativity with prescriptivity and considers that rules cannot be constitutive and regulative at the same time. ${ }^{49}$

As is well known, such a strong version of the objection is defended by Bulygin (1991, pp. 213-214). His position rests on three main arguments. First, whilst constitutive rules are analytic inasmuch as they are definitions, regulative rules or norms of conduct are synthetic in order to be able to fulfill their role to guide behavior (1991, p. 213). Second, in contrast to regulative rules, constitutive rules as conceptual rules or definitions always create an impossibility. Finally, whilst we can distinguish the rule prohibiting certain behavior from the provision for penalties to be exacted if the rule is broken, in the case of legal power-conferring rules we cannot logically distinguish between the rule requiring compliance with certain conditions and the nullity (1991, p. 214).

A good example of the problem of the normativity of the legal power-conferring rules qua constitutive rules can be found in the interpretation of one of the most important theories about legal power. I mean especially the groundbreaking work elaborated by Hart (2012 (1961)).

As is well known, Hart argued that law is a set of two kinds of rules (2012, p. 116). While the primary rules' addressees are

${ }^{47}$ See Klatt 2008, pp. 212-213.

${ }^{48}$ According to Searle, "[r] gegulative rules regulate a pre-existing activity, an activity whose existence is logically independent of the rules. Constitutive rules constitute (and also regulate) an activity the existence of which is logically dependent on the rules" (Searle 2009, p. 34).

According to von Wright, "[p]laying a game is a human activity. It is performed according to standardized patterns, which can be called moves in the game. The rules of the game determine, as I shall say, these moves of patterns - and thereby also the game 'itself' and the activity of playing it. We could say that, when viewed from the point of view of the game itself, the rules determine which are the correct moves, and when viewed from the point of view of the activity of playing, the rules determine which are the permitted moves. It is understood that moves which are not correct are prohibited to players of the game, and that a move which is the only correct move in a certain situation in the game is obligatory when one is playing the game" (Von Wright 1963, p. 6).

${ }^{49}$ See, regarding speech acts theory, Klatt 2008, pp. 212-213. 
required to do or to abstain from certain actions, secondary rules provide their addressees with the power to recognize, create, modify, and eliminate primary rules $(2012$, pp. 81, 94). According to Hart's position, the introduction of the secondary rules provides a remedy for the main defects of a simple customary rules system (2012, p. 94). More precisely, the rule of recognition is introduced in the legal system as a remedy against the uncertainty in identifying the primary rules (2012, p. 94). Indeed, according to Hart the rule of recognition exhaustively defines the necessary and sufficient conditions under which a set of rules can be considered legal by a specific community (2012, pp. 116-117). As pointed out by Shapiro (2009), despite the clarity of the basic idea of the rule of recognition, it is astonishingly difficult to formulate the doctrine with greater precision.

Shapiro (2009) argues that since the rule of recognition is accepted and practiced - that is, it is a social rule - it does not exist in virtue of any other rule, i.e. it is an ultimate rule. In this vein, if a legal official's attitude towards accepting the rule of recognition is the only key for identifying legal officials — or in other words, if legal powerconferring rules amount to the mere practice of practical attitude of acceptance of the rule of recognition -50 then Hart's account is unable to explain the normativity of the rule-conferring legal officials' power. Thus, in contrast to a legal official, although a citizen must have an internal attitude of acceptance towards the primary rules, she does not have to develop this attitude in relation to the rule of recognition. Therefore, even though this citizen must obey the primary rules based on the fact that these rules have been created by legal officials, she cannot find any reason which supports the legal officials' authority (Bernal 2013, p. 173).

It seems plausible to think that a suitable path for explaining the normativity of legal power-conferring rules qua definitions is based on assuming the distinction between internal and external points of view of rules as components of a normative practice. ${ }^{51} \mathrm{As}$ is well known, this distinction was used by Hart in order to show that

\footnotetext{
${ }^{50}$ On the reduction of social rules to social practices in Hart's theory and criticisms against this position, see Shapiro 2011, pp. 102-105.

${ }^{51}$ As stated by Shapiro, although Hart thought that the predictive analysis proposed by Scandinavian realists is a complete mistake, he did sympathize with their impulse to make room for law in the natural world (Shapiro 2006; Hart 2012, pp. 102-103). But not only that, the distinction between internal and external points of view of rules used by Hart bears a strong resemblance to those distinctions introduced by Ross in order to explain the concept of validity (see Ross 1958, pp. 11-18; 34-38).
} 
sanction-centered accounts of rules ignore an essential feature of law (Shapiro 2006). Indeed, according to Hart,

Austin among [some theorists] seeing perhaps the general irrelevance of the person's beliefs, fears, and motives to the question whether he had an obligation to do something, have defined this notion not in terms of these subjective facts, but in terms of the chance or likelihood that the person having the obligation will suffer a punishment or "evil" at the hands of others in the event of disobedience. (Hart 2012, p. 83)

As stated by Hart,

[t]he fundamental objection [against this position] is that the predictive interpretation obscures the fact that, where rules exist, deviations from them are not merely grounds for a prediction that hostile reactions will follow or that a court will apply sanctions to those who break them, but are also a reason or justification for such reaction and for applying the sanctions. (Hart 2012, p. 84)

In this vein, in contrast to other behavioral regularities such as habits, social rules are characterized by a practical attitude of rule-acceptance (Shapiro 2006). As affirmed by Shapiro, this attitude manifests itself not only through acting according to the dictates of the rule (Shapiro 2006, p. 9; Hart 2012, p. 55), but also through the use of the rule in order to justify or to assess one's own or a third party's action (Shapiro 2006) by means of an evaluative language. ${ }^{52}$ In other words, the internal point of view corresponds to a practical use of the rules that an insider performs when she decides how she will respond to the law (Shapiro 2006).

Notwithstanding, along with the practical use of rules, they can be also used as a scheme of interpretation in order to understand a practice. ${ }^{53}$ In this sense, as stated by Shapiro, "an attitude might be external by failing to be a practical attitude at all. Someone whose interest in the law is primarily theoretical, who simply wishes to describe how members of a group regard and respond to a set of rules and, perhaps, to make predictions as well, takes the external point of view" (2006, n.p.). In other words, "the theoretical perspective is that of the observer, who is often but not necessarily an outsider, who studies the social behavior of a group living under law" (n.p.).

${ }^{52}$ See also Ross 1958, p. 11.

${ }^{53}$ In a similar vein see Ross 1958, p. 16. 
As is known, Rescorla has alluded to the particular nature of practices in contrast to mere activities. ${ }^{54}$ Indeed, although both are forms of action, unlike mere activities, practices are associated with internal normative evaluation standards which are coded by means of rules. These rules govern how to run a practice correctly (Rescorla 2009 , p. 101). In this way, unlike mere activities regarding which it is only possible to differentiate between actions which belong to the activity from those which do not, every practice allows a threefold division of actions (p. 101). According to this division, it is possible to distinguish, besides the actions which belong to the practices, those actions which are correctly performed. ${ }^{55}$ This threefold division involves the special relationship that one sort of rules has with the practice, due to the fact that this sort of rules allows one not only to identify some actions as precedents belonging to the practice, but also to assess the singular actions as correct or incorrect. From the theoretical point of view, this group of rules is a necessary condition for the identification of the practice. From the practical point of view, meeting this group of rules is a necessary condition for achieving the aims associated with the practice. Due to their features, the rules belonging to this group can be called constitutive.

In this vein, it is possible to grasp the dual function of the legal power-conferring rules as constitutive rules of the legal practice. ${ }^{56} \mathrm{Ac}$ cording to this position, determining the deontic and the definitional function of the legal power-conferring rules is a matter of perspective. ${ }^{57}$ From the theoretical point of view, the legal power-conferring

${ }^{54}$ According to Rescorla: "sample practices include: dances, like the waltz or the tango; religious ceremonies, like weddings; fraternity initiation rites; performing Beethoven's Fifth Symphony". Sample mere activities are "jumping, bathing, or holding hands" (Rescorla 2009, p. 101).

${ }^{55}$ As Rescorla has written, “[t]he norms for performing Beethoven's Fifth Symphony demand that musicians play the notes of Beethoven's score at roughly the indicated tempo. The norms for dancing the waltz demand that dancers move in time with the music, selecting their movements from a fixed repertoire of dance steps. Agents who violate a practice's norms do not implement the practice correctly, but they may still implement the practice. A devious gambler might repeatedly cheat during a poker game. He plays poker incorrectly, but he plays poker nonetheless" (2009, p. 101).

${ }^{56}$ I am very grateful to Álvaro Núñez Vaquero for his help in thinking about these issues.

${ }^{57}$ See Ross 1958, pp. 11-18; esp. pp. 16-17. According to Ross, "[t]he concept of validity (in chess) involves two elements. The one refers to the actual effectiveness of the rule which can be established by outside observation. The other refers to the way in which the rule is felt to be motivating, that is, socially binding. [...] The concept 'rule of chess' must therefore in any accurate analysis be divided into 
rules play a definitional role, due to the fact that the definition of the participants is a necessary condition for the identification of the legal practice. In contrast, from the practical point of view, the legal power-conferring rules carry out a regulative role, due to the fact that they are necessary conditions for achieving the aims associated with the legal practice. Firstly, although legal power-conferring rules can be expressed as analytic propositions, their definientia can be expressed as synthetic propositions. In this vein, although, from the theoretical point of view, the legal rules of our inquiry are definitions, their definientia must be regarded as regulative norms from the practical point of view - that is, from a participant's perspectivein the sense that they give members of a community, officials and law-subjects alike, reasons for acting. ${ }^{58}$ Secondly, and even more importantly, on the one hand, legal-power conferring rules are in themselves legal power exercises of an (superior) authority, whose purposive interpretation reveals their necessary connection to dutyimposing norms that impose the aims of the legal system. ${ }^{59}$ On the other hand, they "make it obligatory to act according to the norms of conduct which have been created according to the procedure laid down in" procedural rules of legal power (Ross 2009, p. 118). As is well known, this aspect refers to the question concerning the problem of individuating norms,${ }^{60}$ and more specifically, the reduction of legal power-conferring rules to duty-imposing rules (Ross 2009, p. 118). ${ }^{61}$

two: the experienced ideas of certain patterns of behavior (with the accompanying emotion) and the abstract content of those ideas, the norms of chess. [...] The phenomena of chess and the norms of chess are not mutually independent, each of them having their own reality; they are different sides of the same thing. [...] On the basis of what has been said, the following hypothesis is advanced: The concept 'valid (Illinois, California, common) law' can be explained and defined in principle in the same manner as the concept 'valid (for any two players) norm of chess'. That is to say, "valid law' means the abstract set of normative ideas which serve as a scheme of interpretation for the phenomena of law in action, which again means that these norms are effectively followed, and followed because they are experienced and felt to be socially binding" (pp. 16-17). Concordantly, Ross has expressed that "[w] hat distinguishes a directive from a proposition is its operator, which indicates that the topic (being an action-idea) is presented as a pattern of behavior and not that it is thought of as real" (2009 (1968), p. 116).

${ }^{58}$ As we have seen, the expression comes from Postema (1982, p. 165).

${ }^{59}$ Since the aims associated with the practice can be expressed as regulative norms, from the practical point of view there is a necessary connection between constitutive and regulative norms. This relation is compatible with the means-end relationship of a participant's action. (On the thesis of connection between constitutive and prescriptive norms in linguistic practice see Klatt 2008, pp. 109-115.)

${ }^{60}$ See, inter alia, Raz 1970, pp. 140-167.

${ }^{61}$ On the problem of the reduction, see Alexy 2008, pp. 55-62. 
However, the discussion about this issue goes beyond the scope of this paper.

\section{Concluding Remarks}

As expressed above, the goal of this paper was to explore two objections raised against Eugenio Bulygin's second approach to the definition of the nature of legal power-conferring rules. According to this second approach, such rules must be considered constitutive rules - or better said, definitions- (Alchourrón and Bulygin 1991, p. 463) in an exclusive manner, since they do not prescribe any behavior as obligatory, prohibited, or permitted (pp. 462-463).

According to the first objection, inasmuch as Bulygin's second account maintains that these rules can define a variety of heterogeneous phenomena, such an account is vague about what is defined by legal power-conferring rules qua constitutive rules. As we have seen, this problem is rooted in the lack of a suitable definition of legal power. Legal power as "the legally established ability to create legal norms (or legal effects) through and in accordance with enunciations to this effect" (Ross 2009, p. 130) is a special case of competence. In the most comprehensive sense of the term, competence is the ability to follow rules. Since rule-following behavior implies knowledge and intention, it can be distinguished from that behavior that as a matter of fact conforms to some rule or instantiates a law in a causally determined way. Notwithstanding, given that knowledge and intention are mental states which are only accessible by the subject who experiencing them, the actual use of a rule is the only warrant for the fact that it is understood. In consequence, our practices require that competence must be ascribed to the agents. In this vein, the ascription of the ability to follow a normative content to an agent is a speaker's existential presupposition associated with the expression of deontic modalities as conventional specific triggers. Concordantly, every single rule presupposes the ascription of the ability to follow it to an agent - or, in other words, every single rule presupposes a rule that constitutes a competent agent. From the theoretical point of view, the ascription of the ability of following the rules that constitute and regulate a practice to certain agents amounts to their definition as participants of the practice. From the practical point of view, such a definition amounts to the ascription of the ability of following the rules to certain agents in order to justify or to assess one's own or a third party's action by means of an evaluative language. 
As a kind of competence, legal power must be attributed to an agent. Legal power is attributed to an agent by means of a special kind of rules. We call these rules legal power-conferring rules. According to this analysis, it is possible to distinguish between legal power-conferring rules - that is, legal rules that ascribe the ability to follow certain rules in order to create legal norms or legal effects to an agent - and procedural rules of legal power - that is, rules that regulate the use of this ability - as necessary normative conditions for the exercise of legal power. Based on the analytic priority of the former over the latter ones, our inquiry must be firstly focused only on them.

According to the second objection, the non-reductive approach defended by Bulygin cannot explain the normativity of legal powerconferring rules. In other words, this approach cannot explain the authoritative feature of legal power. As we have seen above, Bulygin has defended this approach based on a strong version of the thesis of the separation between constitutive and regulative rules. $\mathrm{He}$ has rested his position on three main arguments, which can be reduced to the problem of analyticity. According to this problem, while constitutive rules are analytic, regulative rules must be synthetic in order to be able to fulfil their role to guide behavior (Bulygin 1991, p. 213). Nevertheless, although legal power-conferring rules can be expressed as analytic propositions, their definientia can be expressed as synthetic propositions. In this vein although, according to their theoretical function, the legal rules of our inquiry must be assumed as definitions, their definientia must be regarded as regulative norms, according to their practical function.

For the sake of clarity, let us take as an example the point of view of an expert in comparative constitutional law who asks who the "President of the United States of America" is, according to the American Constitution. Now compare his perspective with the point of view of the young Obama, who had to meet each of the constitutional requirements for being a President of the United States of America, and the point of view of those subjected to its legal power.

For the young Obama - from the ex ante or before subsumption of the general legal power-conferring rule perspective - firstly, meeting each of the requirements of the definition of this expression - President of the United States of America- was a necessary condition for achieving the aim laid down in the general legal powerconferring rule - which, on the one hand, corresponds to the status created by the definition, and on the other hand, in its turn must 
be harmonious with the aims of the legal system. And secondly, each of these requirements played not only a regulative (motivational) anankastic role over him, but also a regulative (evaluative) role as standard to assess his actions. ${ }^{62}$ Moreover, for those subjected to his legal power - from the ex post or after subsumption of the general legal power-conferring rule perspective - the particular legal power-conferring rule of Obama's office served as legal basis for making it obligatory to act according to the norms of conduct which were created according to the procedures laid down in the rules which determined the way he ought to exercise his legal power (Ross 2009, p. 118) -rectius: procedural rules of legal power.

As we have seen, although legal power must be understood as a special case of competence - that is, as the ability to follow certain kinds of rules - legal power is created - or better said, constitutedby means of a special kind of rules - rectius: legal power-conferring rules. From the practical point of view, legal power-conferring rules must be interpreted as conditions for achieving the aims associated with the legal practice. Concordantly, they must be interpreted as legal basis of those norms of conduct, which have been created according to the procedure established by the procedural rules of legal power. In this way, as stated by Ross, from the point of view of those subjected to the legal power, legal power rules must be considered as "norms of conduct in indirect formulation" (1958, p. $50 ; 2009$, p. 118). ${ }^{63}$

${ }^{62}$ As stated by Ross, "[t]he primary rules of chess, on the other hand, are directives. [...] [T] hey are intended to indicate how the game is to be played. They aim directly, that is, unqualified by any underlying objective, to motivate the player; they tell him as it were: This is how it is played. These directives are felt by each player to be socially binding; that is to say, a player not only feels himself spontaneously motivated ('bound') to a certain method of action but is at the same time certain that a breach of the rules will call forth a reaction (protest) on the part of his opponent" (1958, p. 14).

${ }^{63}$ An earlier draft of this paper was presented at the Special Workshop Bulygin's Philosophy of Law held at the 27th World Congress of the International Association for the Philosophy of Law and Social Philosophy (IVR) at Georgetown University Law Center in Washington D.C., in July, 2015. I am very grateful to the audience, especially Luís Duarte d'Almeida, José Juan Moreso, Stanley L. Paulson, and Juan Ruiz Manero for useful comments and critical remarks. The main arguments expressed in this essay were also presented at the Jurisprudence Symposium held at the University of Milano-Bicocca (Italy) on 14th June, 2017. I would like to express my gratitude to the audience for comments and criticisms, especially Andrea Dolcetti, Francesco Ferraro, Lorenzo Passerini, Michele Saporiti, and Natalia Scavuzzo. I also owe many thanks to Álvaro Núñez Vaquero for his critical remarks on an earlier draft, and finally, I should like to thank Adriel Watt for suggestions and 


\section{REFERENCES}

Alchourrón, C. and E. Bulygin, 1991 (1983), "Definiciones y normas" in C. Alchourrón, and E. Bulygin (eds.), Análisis lógico y derecho, Centro de Estudios Políticos y Constitucionales, Madrid, pp. 439-463.

— 1971, Normative Systems, Springer, Vienna/New York.

Alexy, R., 2008, "Alf Ross' Begriff der Kompetenz", in A. Hoyer, H. Hattenhauer, and R. Meyer-Pritzl (eds.), Gedächtnisschrift für Jörn Eckert: 15.Mai 1954 bis 21.März 2006, Nomos, Baden-Baden, pp. 43-64. Baden.

Austin, J.L., 1966 (1956), "Ifs and Cans" in B. Berofky (ed.), Free Will and Determinism, Harper and Row, New York, pp. 295-322.

Austin, J., 1832, The Province of Jurisprudence Determined, Richard Taylor, London.

Baker, G.P., and P.M.S. Hacker, 1984, Language, Sense and Nonsense, Basil Blackwell, Oxford.

Beaver, D.I., and B. Geurts, 2014, "Presupposition", The Stanford Encyclopedia of Philosophy (Winter 2014 Edition), in Edward N. Zalta (ed.), available at: <http://plato.stanford.edu/archives/win2014/entries/presupposition/> [consulted: 09/10/2016].

Bentham, J., 1970 (1843), Of Laws in General, ed. H.L.A. Hart, The Athlone Press, London.

Bernal, C., 2013, "Austin, Hart and Shapiro: Three Variations on Law as an Entity Grounded in a Social Practice", Rechtstheorie, vol. 44, pp. 157188.

Brandom, R., 1998, Making It Explicit. Reasoning, Representing and Discourse Commitment, Harvard University Press, Cambridge, Mass.

Bulygin, E., 1991, "On Norms of Competence", Law and Philosophy, vol. 10, pp. 201-216.

Chomsky, N., 1980, Rules and Representations, Columbia University Press, New York.

— 1972, Language and Mind. Enlarged Edition, MIT Press, Cambridge, Mass.

- 1966, Topics in the Theory of Generative Grammar, Mouton and Company, The Hague.

- 1965, Aspects of the Theory of Syntax, MIT Press, Cambridge, Mass.

Copp, D., 2008, “'Ought' Implies 'Can' and the Derivation of the Principle of Alternative Possibilities", Analysis, vol. 68, no. 1, pp. 67-75.

Davies, M., 1998, "Language, Thought, and the Language of Thought (Aunty's Own Argument Revisited)", in P. Carruthers, and J. Boucher

advices on matters of writing. Needless to say, none of these scholars is responsible for any errors contained in my paper. 
(eds.), Language and Thought, Cambridge University Press, Cambridge, pp. 226-247.

Ferrer Beltrán, J., 2000, Las normas de competencia. Un aspecto de la dinámica jurídica, Centro de Estudios Políticos y Constitucionales, Madrid.

Frankfurt, H., 1998 (1969), "Alternative Possibilities and Moral Responsibility", in The Importance of What We Care About. Philosophical Essays, Cambridge University Press, Cambridge, pp. 1-11.

Gardner, J., 2013, "Reasons and Abilities: Some Preliminaries", The American Journal of Jurisprudence, vol. 58, no. 1, pp. 63-74.

Hare, R.M., 1963, Freedom and Reason, Clarendon Press, Oxford.

Hart, H.L.A., 2012 (1961), The Concept of Law, 3rd. ed., Oxford University Press, Oxford.

— 1982, Essays on Bentham. Studies in Jurisprudence and Political Theory, Clarendon, Oxford.

Hohfeld, W.N., 1920 (1919), Fundamental Legal Conceptions as Applied in Judicial Reasoning and Other Legal Essays, Yale University Press, New Haven.

Jellinek, G., 1963 (1905), System der subjektiven öffentlichen Rechte, Wissenschaftliche Buchgesellschaft, Darmstadt.

Kanger, S., and H. Kanger, 1966, "Rights and Parliamentarism", Theoria, vol. 32, pp. 85-115.

Kant, I., 1797, Die Metaphysik der Sitten, in Akademieausgabe von Immanuel Kants Gesammelten. Werken Bände und Verknüpfungen zu den Inhaltsverzeichnissen, Abteilung 1: Werke, Band VI; available at: <https://korpora.zim.uni-duisburg-essen.de/Kant/verzeichnissegesamt.html $>$ [consulted: 09/10/2016].

Kelsen, H., 1992 (1934), Introduction to the Problems of Legal Theory, Clarendon Press, Oxford.

— 1991 (1979), General Theory of Norms, Clarendon Press, Oxford. , 1987, "Recht und Kompetenz: Kritische Bemerkungen zur Völkerrechtstheorie Georges Scelles", in K. Ringhofer, and R., Walter (eds.), Auseinandersetzungen zur Reinen Rechtslehre, Springer, Vienna.

—_ 1960, Reine Rechtslehre, 2nd. ed., Franz Deuticke, Vienna.

- 1945, General Theory of Law and State, Harvard University Press, Cambridge, Mass.

Klatt, M., 2014, Die praktische Konkordanz von Kompetenzen. Entwickelt anhand der Jurisdiktionskonflikte im europäischen Grundrechtsschutz, Mohr Siebeck, Tübingen.

—, 2008, Making the Law Explicit. The Normativity of Legal Argumentation, Hart Publishing, Oxford.

Kratzer, A., 2012, Modals and Conditionals, Oxford University Press, place.

Kripke, S., 1982, Wittgenstein on Rules and Private Language. An Elementary Exposition, Harvard University Press, Cambridge, Mass. 
Kurki, V., 2017, "Legal Competence and Legal Power", in M. McBride (ed.), New Essays on the Nature of Rights, Hart Publishing, Oxford, pp. 31-47.

Lindahl, L., 1977, Position and Change, D. Reidel, Dordrecht/Boston.

MacCormick, N., 1986, "Law as an Institutional Fact", in N. MacCormick, and O. Weinberger (eds.), An Institutional Theory of Law. New Approaches to Legal Positivism, D. Reidel, Dordrecht, pp. 48-76.

Makinson, D., 1986, "On the Formal Representation of Rights Relations. Remark on the Work of Stig Kanger and Lars Lindahl", Journal of Philosophical Logic, vol. 15, no. 4, pp. 403-425.

Medina, J., 2002, The Unity of Wittgenstein's Philosophy. Necessity, Intelligibility, and Normativity, State University of New York Press, New York.

Millikan, R.G., 1998, "A Common Structure for Concepts of Individuals, Stuffs and Real Kinds: More Mama, More Milk, and More Mouse", Behavioral and Brain Science, vol. 21, pp. 55-100.

Paulson, S.L., 2000, "The Weak Reading of Authority", Law and Philosophy, vol. 19, pp. 131-171.

Pavlakos, G., 2007, "Two Concepts of Objectivity", in G. Pavlakos (ed.), Law, Rights and Discourse. Themes from the Legal Philosophy of Robert Alexy, Hart Publishing, Oxford, pp. 83-108.

Peirce, C.S., 1933 (1893), "The Essence of Reasoning”, §3 The Nature of Inference, in Ch. Hartshorne, and P. Weiss (eds.), The Collected Papers of Charles Sanders Peirce, vol. IV: The Simplest Mathematics, Harvard University Press, Cambridge, Mass.

Postema, G.J., 1982, "Coordination and Convention at the Foundations of Law", Journal of Legal Studies, vol. 11, no. 1, pp. 165-203.

Raz, J., 1972, "Voluntary Obligations and Normative Powers", The Aristotelian Society, vol. 46, pp. 79-102.

— 1970, The Concept of a Legal System, Clarendon Press, Oxford.

Rescorla, M., 2009, "Assertion and its Constitutive Norms", Philosophy and Phenomenological Research, vol. 79, no. 1, pp. 98-130.

Riesenfeld, D., 2010, The Rei(g)n of 'Rule', Ontos, Frankfurt.

Ross, A., 2009 (1968), Directives and Norms, Humanities Press, New York. , 1958, On Law and Justice, Stevens and Sons, London.

Ruiter, D.W.P., 1993, Institutional Legal Facts. Legal Powers and Their Effects, Kluwer Academic, Dordrecht.

Ryle, G., 2009 (1949), The Concept of Mind, Routledge, London/New York.

Searle, J.R., 2009 (1969), Speech Acts. An Essay in the Philosophy of Language, Cambridge University Press, Cambridge.

Shapiro, S.J., 2011, Legality, The Belknap Press of Harvard University Press, Cambridge, Mass.

2009, "What Is the Rule of Recognition (And Does It Exist?)", Yale Law School. Public Law and Legal Theory. Research Paper Series, Research Paper no. 181; available at: <http://ssrn.com/abstract=1304645> [consulted: 22/03/2014]. 
Shapiro, S.J., 2006, "What Is the Internal Point of View?", Yale Law School; available at: <https://www.law.yale.edu/system/files/documents/ pdf/Faculty/Shapiro_Internal_Point_of_View.pdf $>$ [consulted: 22/03/ $2014]$.

Sinnott-Armstrong, W., 1984, “Ought' Conversationally Implies 'Can”", The Philosophical Review, vol. 93, no. 2, pp. 249-261.

Skegg, PDG, 2011, "Presuming Competence to Consent: Could Anything Be Sillier?", University of Queensland Law Journal, vol. 30, no. 2, pp. 165-187.

Spaak, T., 2005, "The Concept of Legal Competence", The IVR Encyclopeadia of Jurisprudence, Legal Theory, and Philosophy of Law, May 2005; available at: <http://SSRN-id923531\%20(1).pdf> [consulted: 09/05/2016].

— 2003, "Norms that Confer Competence", Ratio Juris, vol. 16, pp. 89-104.

- 1994, The Concept of Legal Competence. An Essay in Conceptual Analysis, Dartmouth, Aldershot, Brokkfield USA.

Stern R., 2004, "Does 'Ought' Imply 'Can'?", Utilitas, vol. 16, no. 1, pp. 42-61.

Strocker, M., 1971, “'Ought' and 'Can'”, Australasian Journal of Philosophy, vol. 49, pp. 303-316.

Timmermann, J., 2003, “Sollen und Können. 'Du kannst, denn du sollst' und 'Sollen impliziert Können' im Vergleich”, Philosophiegeschichte und logische Analyse, no. 6, pp. 113-122.

Tomann, M., 2010, Die Logik des Könnens, Logos, Berlin (Logische Philosophie, vol. 22).

Villa Rosas, G., 2015, “A Matter of Interest. On Robert Alexy's Justification of Practical Discourse", in J. Aguiar, S.L. Paulson, and A. Travessoni Gomes Trivisonno (eds.), Alexy's Theory of Law. Proceedings of the Special Workshop "Alexy's Theory of Law" (held at the $26^{\text {th }}$ World Congress of the International Association for Philosophy of Law and Social Philosophy in Belo Horizonte, 2013), Archiv für Rechts-und Sozialphilosophie, Beiheft 144, pp. 23-64.

Von Brinz, A., 1873, Lehrbuch der Pandekten, 2nd ed., vol. 1, Verlag von Andreas Deichert, Erlangen.

Von Wright, H., 1963, Norm and Action. A Logical Enquiry, Routledge and Kegan Paul, New York.

Werning, M., 2008, “The 'Complex First' Paradox. Why Do Semantically Thick Concepts So Early Lexicalize as Nouns?", Interaction Studies, vol. 9, no. 1, pp. 67-83.

Williams, M., 2010, Blind Obedience. Paradox and Learning in the Later Wittgenstein, Routledge, London/ New York.

— 2007, "Blind Obedience: Rules, Community and the Individual", in M. Williams (ed.), Wittgenstein's Philosophical Investigations. Critical Essays, Rowman and Littlefield, New York, pp. 61-92. 
Wittgenstein, L., 1958, Philosophical Investigations, Basil Blackwell, London.

Yaffe, G., 1999, "Ought' Implies 'Can' and the Principle of Alternate Possibilities", Analysis, vol. 59, no. 3, pp. 218-222.

Table of Cases

Cooper v. Oklahoma, 517 U.S. 348 (1996)

Drope v. Missouri, 420 U.S. 162 (1975)

Dusky v. United States, 362 U.S. 402 (1960)

Estelle v. Smith, 451 U.S. 454 (1981)

Ford v. Wainwright, 477 U.S. 399 (1986)

Foucha v. Lousiana, 504 U.S. 71 (1992)

Godínez v. Moral, 509 U.S. 389 (1993)

Jackson v. Indiana, 406 U.S. 715 (1972)

Panetti v. Qarterman, 551 U.S. 930 (2007)

Rivers v. Katz, 495, N.E. 2d 337 (N.Y. 1986)

Riggins v. Nevada, 504 U.S. 127 (1992)

Sell v. United States, 539 U.S. 166 (2003)

Stewart v. Martinez-Villareal, 523, U.S. 637 (1998)

Washington v. Harper, 494 U.S. 210 (1990)

Received: September 21, 2015, accepted: May 13, 2016. 